\title{
THE IMPORTANCE OF A COMPREHENSIVE ASSESSMENT IN THE TREATMENT OF THORACIC PAIN
}

\section{Susan Lyn Fuller-Good}

A project submitted to the Orthopaedic Manipulative Therapist Group of the South African Society of Physiotherapy in partial fulfilment of the post-graduate course on orthopaedic manipulative therapy.

\section{INTRODUCTION}

Pain from ligamentous capsular and myofascial structures as well as from facet joints and the dura mater can be referred to areas distant from their source, that is, produce somatic referred pain ${ }^{1,2,3,4,5}$. It is the purpose of this study to illustrate the need to assess the spine below as well as above the area of pain, if the source of this somatic referred pain is elusive. In the thoracic spine it is very possible that this may be the case since the basic anatomic information of the enervative and referral patterns of this region is incomplete, rendering a theoretical diagnosis the best possible means of accounting for the pain syndromes encountered ${ }^{3}$.

In the cervical and lumbar regions of the spine, diagnostic blocks and provocation radiology have been used to establish regular somatic-referral patterns. That is, structures suspected of being the cause of pain have been infiltrated with local anaesthetic and pain relief used to implicate the injected structures as the source of the pain ${ }^{6}$. These techniques are the only available means of objectively confirming the cause of pain suspected on clinical examination, but no such work has been done or reported in the thoracic spine $e^{2,3,6}$. Thus, since not enough is yet known about exact referral patterns in this area, careful examination is even more essential.

According to Cyriax, a unique characteristic of dural compression is the "appearance of a localised tender area within the region of false reference, $\mathrm{pg}^{50}$, - a trigger point ${ }^{3,7}$. Further, according to Travell: "the spontaneous pain (from a trigger point) is rarely located at the trigger point responsible for it. Just as pulling the trigger of a gun affects a remote target, so activation of the trigger point projects pain to a distant reference zone $\mathrm{e}^{\prime 4, p g 13}$. This referred pain may be low grade and dull or "incapacitating torture" , pg $13^{3}$, and may occur at rest or only on motion. The finding of a tender area over the area of pain should not mislead the examiner, as this may be referred tenderness that is being palpated. Treatment directed at re-

\section{ABSTRACT}

A case study is presented where unilateral left subscapular pain was treated by mobilisation to the first lumbar segment, as assessment according to the Maitland concept revealed this to be the source of pain. In the treatment of spinal pain, assessment needs to be systematic and where necessary, should include the whole spine, if treatment is to be specific and effective ${ }^{1}$.

\section{OPSOMMING}

Hierdie is 'n gevalle studie waar unilaterale linker subskapulère pyn behandel is deur mobilisering van die eerste lumbale segment. Hierdie segment is as die oorsaak van die pyn erken na ondersoek gebaseer op die Maitland konsep.

Waar pyn sy onstaan in die werwelkolom het, is 'n sistematiese ondersoek noodsaaklik. Indien nodig, moet dit die hele werwelkolom insluit om 'n spesifieke en effektiewe behandeling teweeg te bring'. ferred tender points will be ineffective. Examiners should seek to reproduce exactly the symptoms of which patients are complaining. If treatment is directed at the source of the problem, excellent results can be achieved ${ }^{1,2,3}$. Thus in the thoracic spine it is important to allow theoretical knowledge and clinical findings to enhance one another and not be hindered by total reliance on either one alone.

\section{CASE STUDY}

\section{Present History}

A thirty-four year old female computer programmer presented, complaining of a small area of severe pain felt on the left side of the subscapular region (Figure 1). She had a sedentary job, which involved very long hours of sitting. She had a two year old child whom she lifted and carried quite frequently. She jogged four times a week (four kilometres at a time) and played action cricket once a week for recreation.

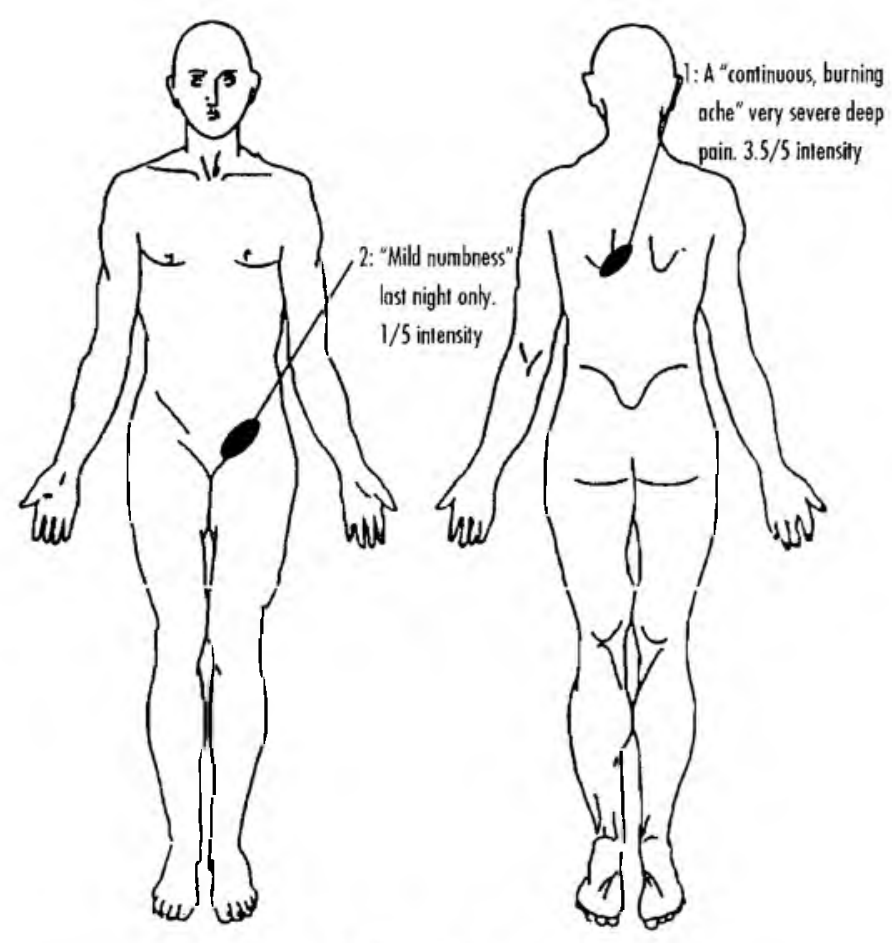

Figure 1. Body chart

She described the pain as a "continuous burning ache," three and a half out of five on a five point pain rating scale 3,5/5. (Figure 1). The aching was qualified as continuous in nature and seemed to be deep seated. The pain (1) was more intense in the evenings and the patient complained of night pain which woke her, but only with movement. Supine was the most comfortable position for sleeping.

Deep breathing and coughing increased the pain to an unbearable intensity. The pain increased to $4,5 / 5$ within ten minutes of sitting. Bending and lifting her child also produced a sharp increase in the pain as did getting into and out of the car. Nothing that she was aware of relieved the pain. The condition was not irritable.

The patient mentioned a mild numbness $1 / 5$ intensity felt in the groin (L1 dermatome) which she had noticed the pre- 
vious evening, lasting for about half an hour. It has come and gone spontaneously; nothing had relieved or aggravated it.

Three days previously she awoke with slight dull subscapular pain. She was unaware of any injuring incident; although she felt the problem had been caused by action cricket played three days prior to the onset of the pain. The pain had increased in intensity until the previous evening when she had called in "agony" for an appointment. She had been advised to rest in bed with a hot pad, supine with a pillow under her knees and to come in the following morning.

\section{Past History}

The patient had an ongoing history of low back pain since the birth of her baby. This pain had been untreated until six months ago, when she first consulted the author. The L4-5 facet joint on the right had been found to be sumptomatic and had responded to unilateral, Gade IV mobilisation I. The pain had not recurred. Four months previously the pationt had prosented with an "acute neck" diagnosed to be discogenic in origin. C4 was the level implicated. It was trated offectively with mobilisations and traction. There was no other past history of note.

\section{Examination: Observation}

On obscriation, she had an increased thoracicks phosis and an exaggerated lumbar lordosis with a slightl poking chin", tight pectoral muscles and slack abdominal musclen, although she was a lean woman. She undressed with caution and was in obvious pain.

\section{Cervical Movements}

Cervical movements were tested first and wereall found to be full range and pain free, except for the lower cervical quadrant test which produced quite severe discomtort in the central neck area about the level of C4-5.

\section{Thoracic Movements}

Spontaneous forward flexion was from the hips with head held up and back straight. A sharp increase in pain was produced when the movement was corrected. Thoracic movements were more limited than the cervical movements. Notest movement significantly increased the constant subscapular pain cxcept for loft side flexion which was not as painful as II, 3 Int in, in!

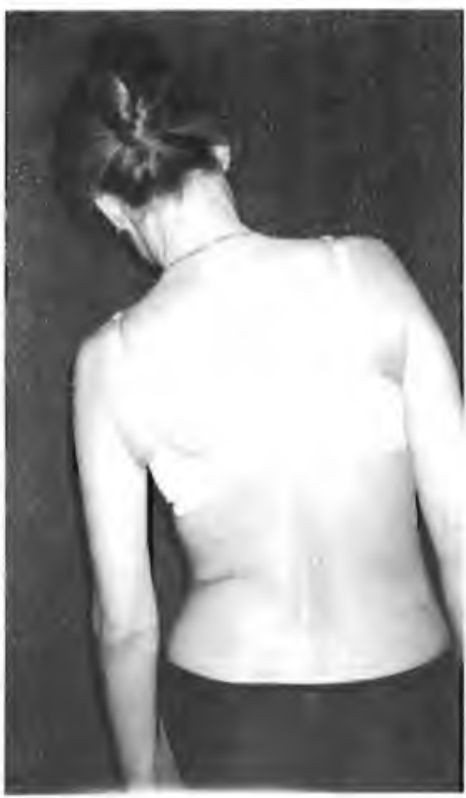

rigure 2 Leff side flexion

\section{Lumbar Movements}

() n the basis of the reperted numbiness of the previouserening, it was deined 10 examine the lumihas spine as well in order to find a true objectivecomparable sign. l.umbar flexion Mis grossly limited (tingrerlips to top of patella - - 0,5 of the range of movement) and was performed in the - Ime manner an thoracic mwat flexion described bove. Slight correction of hend position inte flexion produced a dramatic in- rease in the subscapular pin. Extension was very limited $(0,25$ of the range of movement) and slightly increased the subscapular pain. I.eft side flexion produced $5 / 5$ p.in when the fingertips reached half way down the thigh (0,25 of the range) (ligure 2).
Most of the movement occurred in the upper thoracic region. Marked stiffness was evident at the thoraco-lumbar junction.

Although the objective examination had been extensive, despite all the movement, the constant pain had not increased except momentarily. Each test movement performed had been crucial to making an accurate diagnosis. It was decided to leave the tension tests for the following day as the examiner already had an accurate indication that neural tissue was involved as the subscapular pain was markedly worsened by the addition of even slight neck flexion, which would increase the stretch on the neural tissue. An upper and lower limb neurological examination had revealed nothing abnormal. Thoracic sensation was also normal. An objective comparable sign had been easy to find - left side flexion.

\section{Palpation}

On palpation, tenderness and trigger points were found over the painful area, but nothing else of note was revealed in the thoracic spine. In the lumbar spine, protective muscle spasm was found over the L1-L2 paraspinal area on the left and was frinful even on gentle pressure over this area.

Tightness and thickening were noted, as six months previously, (Nell the $1+-5$ and the L-5-S1 facet joint structures on the right

Central, unilateral and transverse pressure' on T6-12 vertebrac produced noeflect on the pain. Unilateral pressure on L1 on the left produced a "jump" response t.pg 3.7.p.t. and intense pain $\overline{5} / \overline{5}$ from the commencement of the movement. Central and transierse pressure on this same joint, produced a less violently painful, but similar response when movement was taken slightly into resistance (IV - ') for one second.

\section{Treatment}

Treatment on day one was limited since so much movement had already been produced during the examination. As described by Maitland extremely gentle, rhythmical and smooth transverse pressures towards the left were performed on the I.1 transverse process, short of any resistance, for 30 seconds. The patient was reassessed - the continuous subscapular pain was less intense $2,5 / 5$ and left side flexion had increased to 0,5 of the range, but was still limited by the severe subscapular pain 4/5. The procedure was repeated for a further 90 seconds, after which therewas still more improvement and deep inspiration no longer increased the pain. Side flexion to the left was still 0,5 of the normal range, but produced less serere pain 3/5. The treatment was followed by fiftern minutes of interferential therapy in right side lyingover two pillows to further open the 1,1 facet joint on the left (lighure 3). The patientwas advised to sit for short periods only and bo lic in right wide lying over a pillow bo continue the

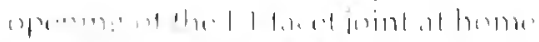

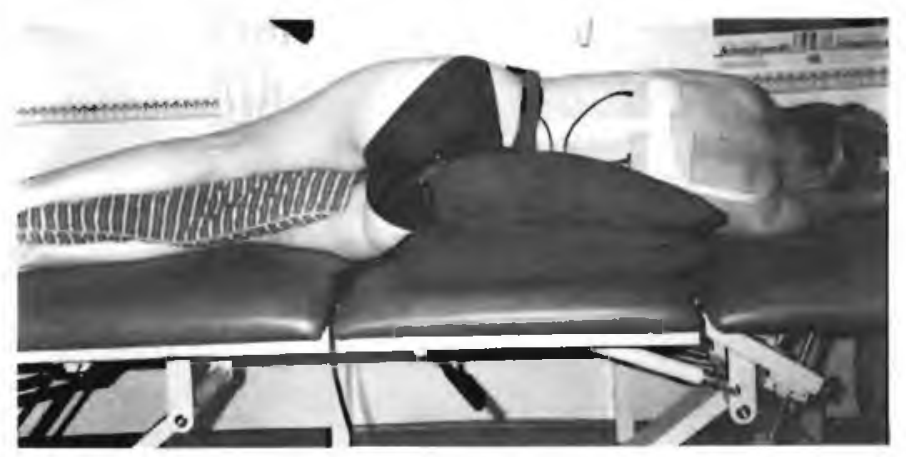

"igure 3 interterenlial in sidte lying

The following day the patient presented with low intensity $1,5 / 5$, constant subscapular poin and reported feeling like a 
"new person". The subscapular pain (Figure 1:1) had returned to $3,5 / 5$ intensity the previous evening. She had been able to sit for 90 minutes before this pain had increased, and deep breathing produced only a marginal increase in pain. Left side flexion was still only to the knee and painful 3/5, but forward flexion was much inproved to mid-shin and produced only a slight increase in pain. In view of this favourable response, the treatment was repeated using small amplitude movements slightly into resistance (IV) ${ }^{\prime}$ for five sets of 30 seconds cach. Reassessment at this point revealed that the continuous subscapular pain had cleared and even deep breathing did not bring it back. Left side flexion was full range (two fingers below the knee) and produced minimal pain, only when the position was sustained for ten seconds. The technique was repeated on the T12 spinous process and the L2 transiverse process using small amplitude movements at the end of range $(\mathrm{IV}+)$. Trigger point therapy was used to the quadratus lumborum and erector spinac muscles where tender point were found. Most of the tenderness tound previously, ore the polinful ares h.m s:ern

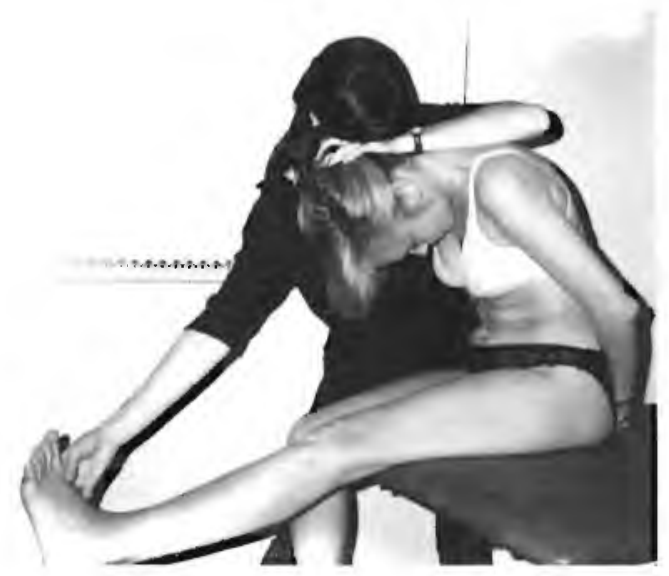

igure 4 , lie slump test

No trostmont was siven on the lhird dal recelastreatment was on the fourth das The palient was pain frese on arival, and lifting her inild 170 longer produced ans. pain I cirt side flowol was completely clear exen with orer pressure liken foll "loose" and was pain frocexcept with passively enfored nech flexion. The "slunp test" (1,3;10) was perforned at this shage and was found to be positive especially on left knce extemaion (Figure 4). It was decided that since the pationt had not flared up with treatment that a vigorous technique could be used and the patient was placed inte the "slump" position and held quite firmly while loft knce flexion and extension ucre performed slightly into resistance 60 times, with continued rosssessment during this poriod. Reassessment, after the proformance of the technique, revealed a marked increase in flexion -

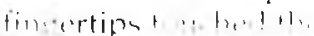

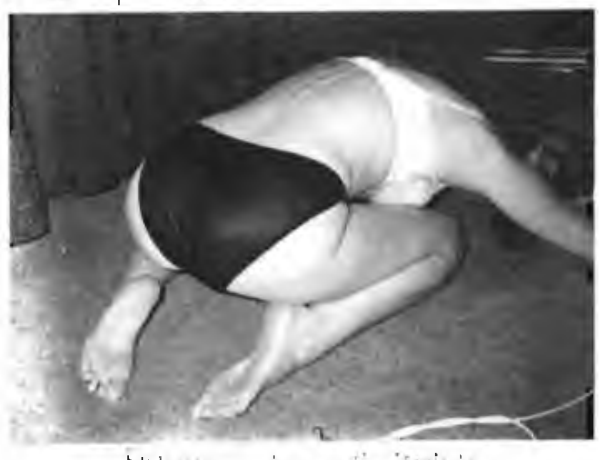

The paticint was hound a home co"rise prosingmom and disclinged, knowing sho should rolurn at the slightent re man of pain. progianme inluded much ont whates hat borl shomensix momble before at the pre

vious episode and was thorefore cxtensive. Sho was a khel to "pply the "slump" troatment to herself for 30 scounds a das and to "cat stretch" right into lateral flexion, by walking hor hands to the right side (figure 5) in order to mobiline herealt as had been done with the treatment. She was retaught back extensor and abdominal muscle strongthening as well as the strengthening of the lower and middle fibres of the trapezius muscles, in order to inprove her posture. Lastly she was reminded of previous advice as regards kinetic handling especially when lifting her child, ergonomics and the dangors of prolonged sitting and the necd for hourly "Mckenzic extension" exercises" "?

Telephonic follow up throe wecks later found the patient feeling well and exercising as instructed. She was leaving for Australia, thus preventing further follow up. There has been no flare up from the vigorous stretching at the last session.

\section{DISCUSSION}

This study is based on the Maitland concept, the kevistones of which are: the need for continuous analytical assessment and the relationship botwe'n joint movement and pain rosponsel. The results are a clour cut demonstration of how: "Assessment is the koy to uncous! II and it may be clararly scen from this study that the wholo ypino may need to be assessed and that treatment should not commonce until the pationt's cxact pain has been reproducod. Troatment of the area of referred tenderness establiahed on palpation would haveproduced unsatisfactory results. The morits of a thorough subjective assessment can also be seon trom this example, as the patient had given the clue to the source of the sivmptoms by indicating that she had had numbmess in the l. I dermatome the previous evening. This important fact would have been missed had the information mot boen carefully tocumented.

On the basis of the assessment, it was diagnosed that the L1 motion segnent was responsible in some way for the loft subscapular pain. This diagnomis was confirmed by the fact that the patient was quichly and completely relioned by the trontment administered. I future study could be to use an anasthetic block, injectod into upecific structures of the interrertebral segnent, in order to ascerlain exactly what compoment was producing the simptoms

There is little data on the topic of thoracic poin. Insufficient studies have been dono on thoracic pain patterns, thorefore pain in the thoracic region poses many diagnostic difficulties in that there is no consistent doumented location for roferred pain from a particular segment. The area of referred pain can therefore not be used to deduce the earct segmental location of its source"s," More studice of them nature nead to be undertaken in order to establish thumcic pain patterns and possible sites for pain referral.

Two tissues are suggrested as pumible sombes ot the un-

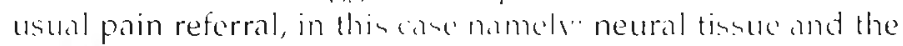

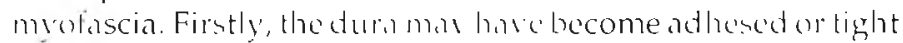
as a result of both the previnum neck and back problems. This mas have produced am immoblits problem, resulting in trigger points $5,5,12$. This dintunction ma have prodisposed the pationt to become symplomatic willout an injuring incident. The already tight and potentialls wimptomatic dusal shesth could have been irritated b traction or inflammatore reaction chemicals. A discogenic, ligamentous, or capsulal suelling at the I. I intervertebral lexel ma have produced the traction eftect on the membrane" " (hemicale produced buthe inflanmatory reaction of an intlamod, and damaged joint ma lave irritated the chemo-sensitise durst ${ }^{-}$The T6 vertebrs, is the physiological tension point of the lnoracic dura", theretore the mid thoracic spine now has been the area most affected by the dural irritation. This meuld aplain why pain emamating from the L1 motionsogmentwantelt in the subscapular rogion. socondly, afferent discharge from a dincased or damalgodjoint 
namely $L_{1} 1$, may cause a latent trigger point to become active. This may cause "agonising incapacitating pain"t,pst. Reflex, protective splinting of muscles a round a painful joint perpetuates this cycle, reactivating trigger points and bringing other trigger points into action ${ }^{4,7,12}$. The muscles and fascia involved include, iliocostalis and longissimus ${ }^{2}$, latissimus dorsi and the thoracolumbar fascia or erector spinae aponeurosis, among others $^{14}$. Thoracic longissimus as well as thoracic iliocostalis affect both the thoracic and lumbar regions as they originate in the thoracic spine and insert into the lumbar spine and pelvis. Both contribute to the action of side flexion - the most painful movement for this patient. According to Travell, contraction of a muscle containing a trigger point produces pain ${ }^{4}$.

The mechanoreceptor stimulation associated with manipulative procedures, such as transverse pressures are used in the study, produces presymaptic inhibition of nociceptive afferent transmission ${ }^{15}$ and, in this way, could be responsible for relieving the patient's pain. This technique was chosen as more movement could be produced on the contralateral side, because the ipsilateral side was so tender, and the aim of the treatment was to "open" 1 pg 286 the joints which were painful when closed - that is when the patient side flexed to the left. Treatment objectives could be achieved, even without a confirmed diagnosis.

\section{CONCLUSION}

Assessment must be thorough if treatment is to be effective. It appears from this case study that the I_ I-2 motion segment may refer pain upwards towards the subscapular region. Al- though the mechanisms for this are not documented, two possible explanations are suggested. Further studies are required before this can be properly proven and understood.

\section{References}

1. Mailland G D. Virtebrul Manipulation. 5th ed. Londenn: Butterworth $1986: 3-13,(68-69), 12 !-123,144-17(), 233-237,262-269), 285-2866$.

2. Twomey L T, Tavlor I R. Plysical Therapy of the Lot binck. Australia: Churchill livingstonc 1988:91-98,103-131,137,146-153,245-249.

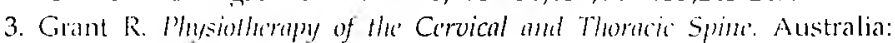
Churchill L..ivingstone 1988:27-37,58-77,97,243

4. Travell I D, Simens M D. Myofascint Pain and Dysfundion. The Trigyer Poiml Minuml. Willians \& Wilkins 1983:2-6,16.

5. Cyriax J. Mechanisms of Symptoms. Dural pain. Lancit I, 1978:9(9)-921.

6. Bogduk N, Twomey L T. Pathological Anutomy of the Lambar spine. Clinical Anatomy of the Lumbar spine: Chapler 1 4:139-147.

7. Pullen S I. Myofascial Pain: A Review. SA foumal of Mhysiotherapy $19(2): 48(2) ; 23-25$.

8. Feinstein B. Langton J B, Jameson R M ot al. Experiments on Referred Jain from Deep Somatic Tissues. / Bone foinl Surse 1654:36A:981

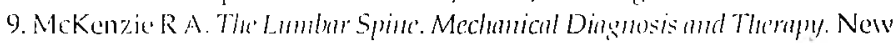
Zcaland: Spinal Publications 1981:62.

10. Mailland $G_{1} D$. The Slump Test: Examination and Treatment. Aust I Mhysio $1985: 31(6) ; 215-219$.

11. Coales H, King A. The l'aticnt Asse'ssment: Churchill Livingstone 1982:15.

12. Pullen S I. Myofascial Pain: A Review. SA fommol of Mhysiolhempy $(0) 2: 48(3) ; 37-39$

13. Course Nutes Jull G. Johannesburg 1991: As recorded by Helen David.

14. Bugduk N. A reappraisal of the Anatomy of the Lumbar Lrector Spinae. I M $m u l: 131(3) ; 525-540$

15. Whyte B D. Articular Neurology and Manipulalive Therapy. Aspects (f) Manipulative Therapy. Proceedings of the Conference on ManipuLative Theraso: Melbourne 1974:72-77.

\section{ARE YOU CONSIDERING A MOVE
OVERSEAS: HOW ABOUT THE UK?}

The opportunities for South African physiotherapists to work in the UK either on a working holiday or a more permanent basis are still excellent. The best way to start the process is by talking to someone with specific experience in this market. One expert in this field is BBT Medical. Over many years they have developed an outstanding reputation for assisting South African physiotherapists to work and live in the United Kingdom. They were the first UK agency to advertise on these pages and have continuously worked to promote South Africans skills and abilities, enhancing reputations throughout the UK. Although UK based they are often referred to by UK managers as "The South African Agency."

Having returned from a recent series of recruitment seminars in RSA, they were once again very impressed with the standard of the therapists they met. They are very keen to continue to help
South Africans spend time in the UK and have found that over the years our reputation has continued to grow!

Covering every hospital in the UK for the ideal position is not easy. (There are hundreds of hospitals) but BBT do just that, resulting in an excellent choice of assignments. We all have our own individual requirements when going overseas and a personal touch is an absolute priority. From a therapists first contact, the same recruitment consultant helps not only find the ideal position but ensures that a therapist's time in the UK is a success.

As part of their service they offer:

- Contracts of any length

- Arranged accommodation

- Help with UK entry clearance

- The top rates of pay

- Exclusive contracts

- Mail forwarding

- Computerised weekly payment
- Free tax and banking advice

\section{- UK holiday information}

\section{- Ongoing support}

BBT considers one of the most essential things to organise to be your CPSM membership (similar to the S.A.M.D.C.). For physiotherapists taking their first locum position in the UK they assist therapists through this process and refund the cost of the registration fee in one go - that is currently $£ 302.00$ !

If you would like to know more about working in the UK, then Richard Smith or Joanna Morris from BBT in London are very happy to talk to you on the free number below. Do not forget to ask for their information pack.

Telephone FREE - 0800998154

BBT - Medical,

14 Buckingham Palace Road,

London SW1W OQP

Fax: 0944171233 8004/5

E-mail: recruit@bbt.co.uk 